\title{
INHIBITION OF CORTICOID-INDUCED PARTURITION BY PROGESTERONE IN CATTLE: EFFECT ON DELIVERY AND CALF VIABILITY
}

\author{
W. JÖGHLE, H. ESPARZA, T. GIMÉNEZ AND M. A. HIDALGO \\ Institute of Veterinary Science, Syntex Research, \\ Palo Alto, California, U.S.A.
}

(Received 22nd March 1971, accepted 28th Fune 1971)

\begin{abstract}
Summary. Progesterone ( $100 \mathrm{mg}$ ) applied 3 days before and 5 days after a single administration of $10 \mathrm{mg}$ flumethasone on Day 270 of pregnancy in sixteen cows and thirteen heifers, successfully prevented premature parturition which was otherwise promptly induced by the corticoid. At this dose level and timing, progesterone interfered significantly with the sequence of events preceding, accompanying and following parturition. As a result, preparation of presentation of the fetus for parturition was either delayed or prevented, dystocia was frequent, the percentage of stillborn calves was significantly elevated, calf viability was impaired and placental retention, which occurs in about $80 \%$ of corticoidinduced parturitions, was not influenced.
\end{abstract}

\section{INTRODUCTION}

Corticoids, if supplied during the last trimester of pregnancy in cattle, but specifically during the last 40 days of the gestation period, induce premature parturition of the fetus (Adams, 1969; Adams \& Wagner, 1970; Brown, Hidalgo, Sickles \& Jöchle, 1970; Karg, Böhm, Günzler \& Müller, 1971; Osinga, Stegenga \& Jöchle, 1971; R. Welch, personal communication). The placenta is retained in about $80 \%$ of all cases, but is discharged within 8 to 14 days without complications if adequate general and/or intrauterine antibiosis is provided (Jöchle, 1971). Nevertheless, retention of the placenta is a main obstacle for the widespread use of corticoids as a management tool in the cattle industry.

In this respect, corticoid-induced parturition closely resembles two conditions described in cattle: (a) retained placenta is common after a twin pregnancy (Comberg \& Velten, 1962; Daerr \& Grunert, 1970), which is generally terminated 8 to 12 days before the calculated term (Hewitt, 1934; Boyd \& Reed, 1961) probably owing to the presence of four fetal adrenals and their parturition-inducing surge in corticoid output; (b) viable offspring are born but the placenta is retained if cows are ovariectomized at the beginning of the third trimester of pregnancy. Gestation is maintained without progesterone substitution, but is terminated by spontaneous premature parturition early in 
the 9 th month. This effect can be counteracted by supplying $100 \mathrm{mg}$ progesterone daily from Day 248/260 to Day 278, a treatment which is followed by spontaneous parturition of both fetus and placenta (McDonald, McNutt \& Nichols, 1954).

The purpose of this study was to determine the effect of progesterone on corticoid-induced parturition in groups of pregnant cows and heifers. It was our hope either to counteract the corticoid effect entirely or to obtain expulsion of the fetus and subsequently of the placenta at a predictable interval from corticoid administration.

\section{MATERIALS AND METHODS}

Sixteen Canadian Holstein cows with known insemination dates and thirteen heifers of the same breed for which the insemination date was somewhat less reliable but palpation confirmed that their pregnancies were approaching termination, were allotted at random to two groups. Group I received $10 \mathrm{mg}$

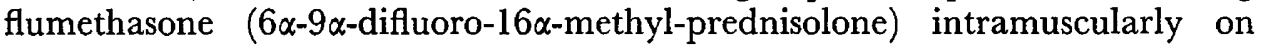
Day 270 of gestation only. Group II received the same dose of flumethasone on Day 270; progesterone treatment, $100 \mathrm{mg}$ intramuscularly daily, commenced on Day 268 and was continued until Day 275, if not terminated by parturition before this date.

The status of the animals was recorded twice daily and signs of pending parturition were scored. Births were, whenever possible, attended and were assisted when necessary.

Retention of the placenta was diagnosed when spontaneous placental delivery was not observed within $24 \mathrm{hr}$ post partum.

\section{RESULTS}

All observations made and data collected are tabulated in Tables 1 and 2. An injection of $10 \mathrm{mg}$ flumethasone alone was successful in inducing parturition within 2 to 3 days in five out of seven cows and four out of seven heifers. In one heifer, although all the signs of impending parturition were observed, delivery did not take place until 7 days later (Table 1). Induced parturitions were associated with an unusually high frequency (50\%) of dystocia; no dystocia was recorded in those animals which were unaffected by flumethasone. Placental retention was observed in all animals with induced delivery, and in $75 \%$ of the animals with spontaneous delivery (Table 2).

Progesterone treatment successfully counteracted the flumethasone effect in a significantly high number of cows and in a significantly high proportion of the total number of treatments (Table 1). In all animals in which progesterone delayed parturition, signs of impending parturition were also suppressed until spontaneous parturition was approaching. This was usually 4 to 5 days after the cessation of the progesterone treatment period (Table 2).

Dystocia (defined as delayed parturition and the necessity to render assistance to the mother either by correcting the calf's position or by applying traction to assist or to complete delivery of the fetus) occurred in all progesterone-treated 
animals which responded to corticosteroids with induced parturition. It also occurred in eight out of eleven animals in which progesterone had prevented induced parturition (Table 2). The same frequency of distribution was recorded for retained placenta (Table 2). While no case of stillbirth was observed after flumethasone alone and calf viability was excellent, two out of four calves produced during the progesterone treatment period, and three out of eleven calves produced 4 to 5 days after cessation of progesterone treatment by spontaneous delivery were stillborn (Table 2). No losses of cows or heifers were seen after flumethasone alone, but one heifer died on the 7th day of the progesterone treatment course (preparturition toxaemia and hypocalcaemia) and one heifer died 3 days post partum (postparturition toxaemia and puerperal sepsis).

TABLE 1

INDUCTION OF PARTURITION BY FLUMETHASONE ON DAY 270 OF GESTATION AND EFFECT OF PROGESTERONE APPLIED FROM DAY 268 TO 275 IN COWS AND HEIFERS

\begin{tabular}{|c|c|c|c|c|}
\hline Treatment & Response to flumethasone & No. of cows* & No. of heifers $\dagger$ & Total $\%$ \\
\hline$I: n=14$ & $\begin{array}{l}\text { (a) Parturition induced } \\
\text { (b) Incomplete induction of } \\
\text { parturition } \\
\text { (c) No effect }\end{array}$ & $\begin{array}{l}5^{(5)} \\
-\end{array}$ & $\begin{array}{l}4 \\
1 \\
2\end{array}$ & $\begin{array}{l}9= \\
1= \\
4=\end{array} \begin{array}{l}71 \cdot 4^{(1)} \\
28 \cdot 6^{(2)}\end{array}$ \\
\hline II $: \mathbf{n}=15$ & $\begin{array}{l}\text { (a) Parturition induced } \\
\text { (b) Incomplete induction of } \\
\text { parturition } \\
\text { (c) No effect }\end{array}$ & $\frac{-}{9^{(6)}}$ & $\begin{array}{l}3 \\
1 \\
2\end{array}$ & $\begin{aligned} 3 & = \\
1 & = \\
11 & =73 \cdot 9^{(4)}\end{aligned}$ \\
\hline
\end{tabular}

Treatment I: $10 \mathrm{mg}$ flumethasone on Day 270; Treatment II: $10 \mathrm{mg}$ flumethasone on Day 270 plus $100 \mathrm{mg}$ progesterone from Day 268 to 275 .

Significance: ${ }^{(1)}$ versus $^{(3)}: P<0.04 ;^{(2)}$ versus $^{(4)}: P<0.04 ;^{(5)}$ versus $^{(6)}: P<0.005$.

* Conception date accurate.

† Conception date possibly not accurate.

\section{DISCUSSION}

According to expectation, flumethasone at the chosen dose level induced parturition at a predicted interval from treatment in a high percentage of animals.

Contrary to expectation, progesterone treatment counteracted the corticoid effect, but did not assist removal of the placenta. A clearly detrimental effect on the sequence of events preceding, accompanying and following parturition in cattle was recorded: there was obvious interference with those fetal movements normally observed close to term, which are responsible for the proper fetal position for parturition (Rüsse, 1965) and labour and delivery mechanisms were impaired to an unusually high degree. Although there was an unexplained tendency for the entire herd to suffer from dystocia and retained placenta, administration of progesterone aggravated these conditions. The effect was most pronounced on calf viability before and after parturition (Table 2).

A single case was reported by Wright, Settergren, Saagman \& Hansel (1970) in which $100 \mathrm{mg}$ progesterone counteracted $20 \mathrm{mg}$ flumethasone given on Day 245. Pregnancy was maintained by a daily injection of $100 \mathrm{mg}$ progesterone, 


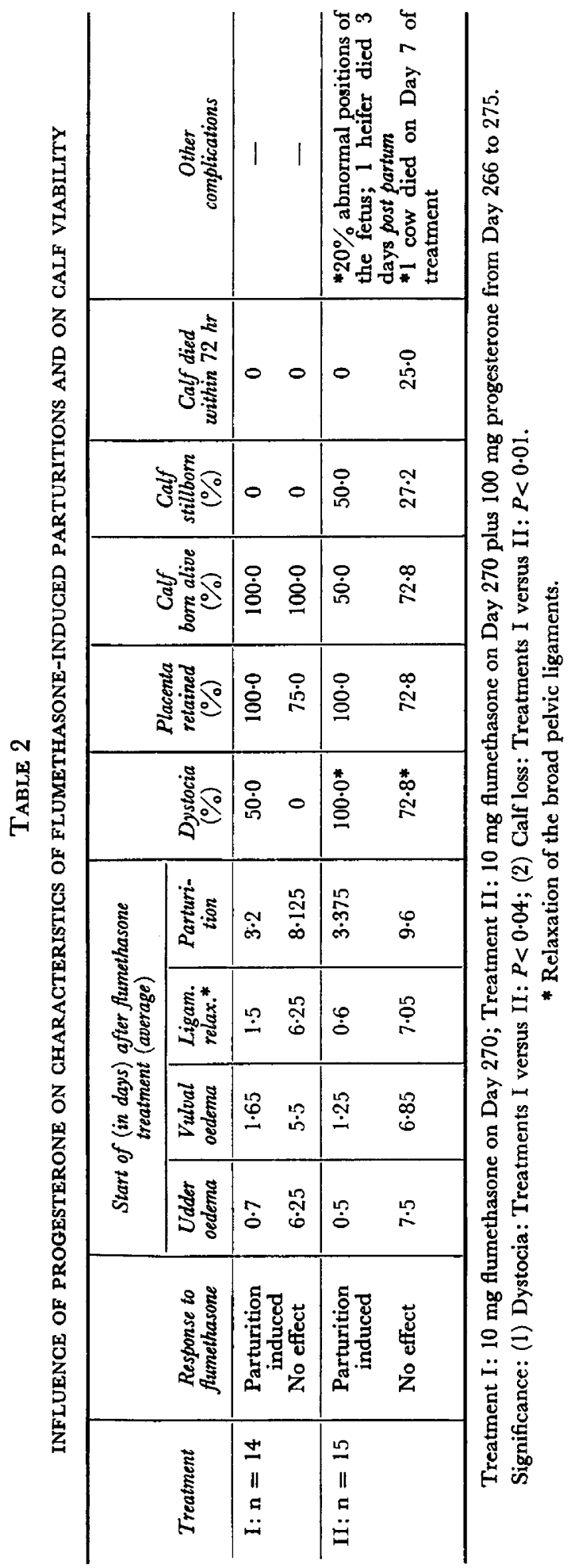


although the flumethasone-induced drop in plasma progesterone levels was evident and no effect of the applied progesterone on plasma levels was observed. This finding and those cited by McDonald et al. (1954) and Tanabe (1966, and personal communication) suggested that the progesterone dose chosen might be high enough to counteract the corticoid effect but not to interfere with the endogenous progesterone levels which, at this stage of gestation, are already declining as shown recently by Pope, Gupta \& Munro (1969), Hoffmann \& Karg (1970), Karg, Schams, Hoffmann \& Böhm (1970), Donaldson, Bassett \& Thorburn (1970) and Stabenfeld, Osburn \& Ewing (1970).

Efforts to use synthetic oestrogens (DES), before or simultaneously with flumethasone (R. Welch, personal communication; Karg et al., 1971) to speed removal of the placenta, have failed and have also induced dystocia. Natural oestrogens have been successfully used in ten out of thirteen animals treated close to or immediately after calculated term, but resulted in seven cases of retained placenta (Grønberg-Pedersen, 1969). This indicates that the crude approaches adopted, which were seemingly justified by the dramatic changes in endogenous endocrine balance towards the end of the gestation period in cattle, do not allow for correction of partial failures of an otherwise remarkably effective method for the induction of parturition in cattle by a single corticoid administration.

The question of whether retention of the placenta can be artificially controlled by hormonal mechanisms remains undecided.

\section{REFERENCES}

Adams, W. M. (1969) The elective induction of labor and parturition in cattle. F. Am. vet. med. Ass. 154, 261.

Adams, W. M. \& Wagner, W. C. (1970) The role of corticoids in parturition. Biol. Reprod. 3, 223.

BOYD, H. \& REED, H. C. B. (1961) Investigations into the incidence and causes of infertility in dairy cattle. Br. vet. J. 117, 18, 74, 192.

Brown, W., Hildalgo, M. A., Sickles, J. \& Jöchle, W. (1970) Synthetic corticosteroid induction of parturition in cows. Symp. Dtsch. Ges. Endokrin., 16, 303. Springer, Berlin.

Comberg, G. \& Velten, U. (1962) Der Einfluss von Zwillingsträchtigkeit auf Fruchtbarkeit und Leistung beim schwarzbunten Niederungsrind. Züchtüngskunde, 34, 49.

Daerr, H. C. \& Grunert, E. (1970) Gesundheit und Fruchtbarkeit von deutschen schwarzbunten Rindern nach erschwerter Zwillingsgeburt. Dt. tierärztl. Wschr. 77, 201.

Donaldson, L. E., Bassett, J. M. \& Thorburn, G. D. (1970) Peripheral plasma progesterone concentration of cows during puberty, estrous cycles, pregnancy and lactation, and the effects of undernutrition or exogenous oxytocin on progesterone concentration. F. Endocr. 48, 599.

Grønberg-Pedersen, H. (1969) Partus provocatus hos koen. Nord. Vet Med. 21, 591.

Hewirt, A. G. T. (1934) Twinning in dairy cattle. F. Dairy Res. 5, 101.

Hoffmann, B. \& KARG, H. (1970) Determination of progesterone in bovine peripheral plasma under different physiological conditions using the competitive protein-binding method. IIIrd Int. Congress on Hormonal Steroids, Hamburg, Excerpta Med. Fdn, ICS, 210, 104.

Jöchle, W. (1971) Corticosteroid induced parturition in domestic animals: mechanism of action and economic importance. Folia vet. latina, Roma, 1, (in press).

Karg, H., Böhm, S., Günzler, O. \& Müller, S. (1971) Erfahrungen über die Geburtseinleitung beim Rind mit Glucocorticoiden. Dt. tierärztl. Wschr. 78, 35.

Karg, H., Schams, D., Hoffmann, B. \& Böнm, S. (1970) Blood levels of prolactin, LH and progesterone in cows before, during and after normal resp. corticoid-induced parturition. Symp. Dtsch. Ges. Endokrin. 16, 301. Springer, Berlin.

MaDonald, L. E., McNutr, S. H. \& Nighols, R. E. (1954) Retained placenta. Experimental production and prevention. Am. J. vet. Res. 15, 22.

Osinga, A., Stegenga, Th. \& Jöchle, W. (1971) Initiation of parturition in dairy cows with a synthetic corticosteroid. Zuchthygiene, 6, 64 . 
Pope, G. S., Gupta, S. K. \& Munro, I. B. (1969) Progesterone levels in the systemic plasma of pregnant, cycling and ovariectomized cows. F. Reprod. Fert. 20, 369.

Rüsse, M. (1965) Der Geburtsablauf beim Rind. Arch. exp. VetMed. 19, 763.

Stabenfeldt, G. H., Osburn, B. E. \& Ewing, L. L. (1970) Peripheral plasma progesterone levels in the cow during pregnancy and parturition. Am. 7. Physiol. 218, 571.

TANABE, T. Y. (1966) Essentiality of the corpus luteum for the maintenance of pregnancy in dairy cows. 7. Dairy Sci. 49, 731.

Wright, J. N., Setrergren, I., SaAgman, R. R. \& Hansel, W. (1970) Peripheral plasma progesterone levels in pregnant cows treated with flumethasone. Soc. Study Reprod. 3rd Ann. Meet., Columbus, Ohio (Abstract). 